\title{
European Journal of
}

\section{Philosophy, Culture and Religious Studies}

(EJPCR)

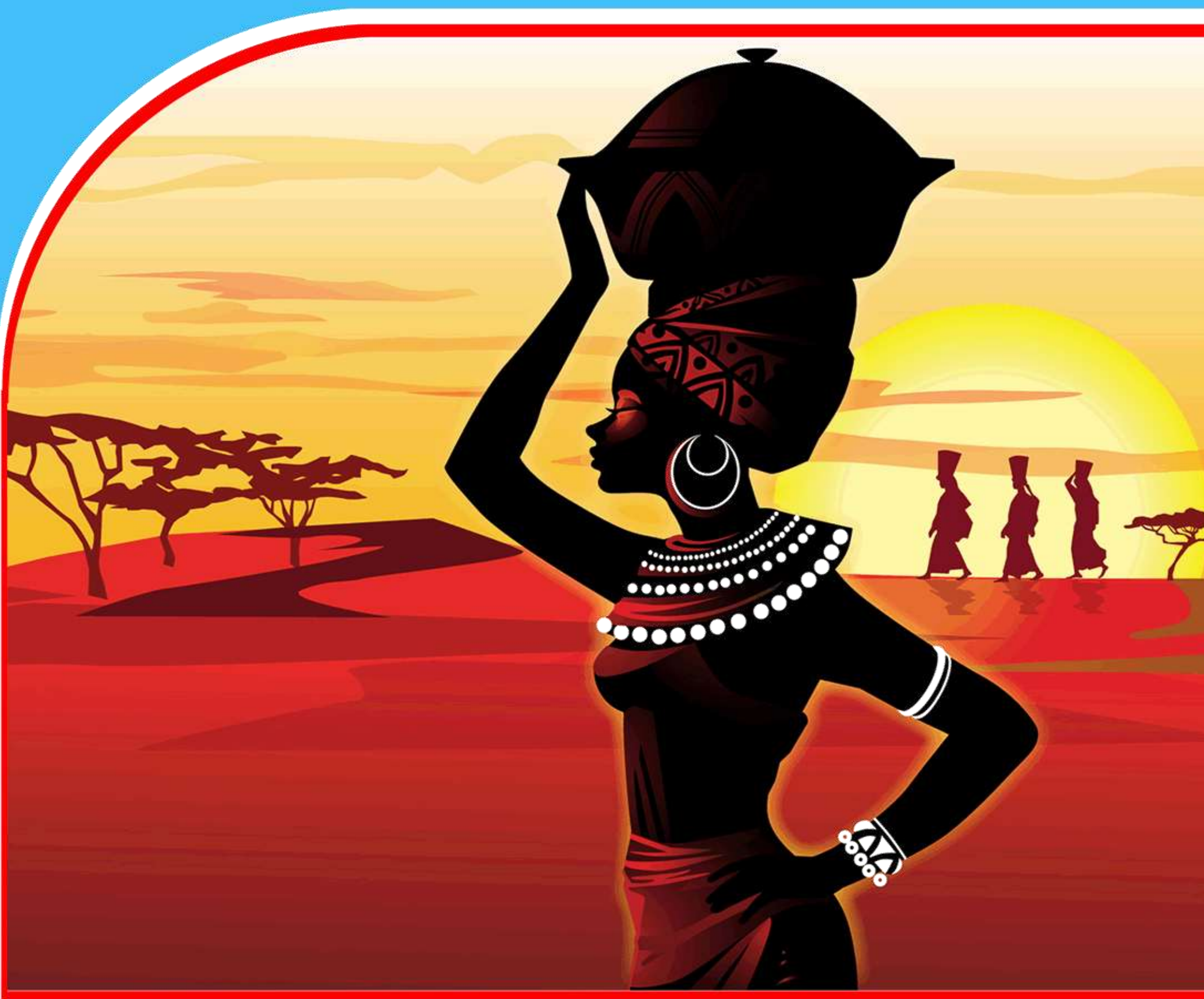

Fight Against Corruption:

A Christian Medieval Historical Period Approach

Elijah Nderitu King'ori 


\title{
Fight Against Corruption: A Christian Medieval Historical Period Approach Elijah Nderitu King'ori \\ Student: Nairobi Evangelical School of Theology \\ Africa International University \\ Author's Email: elijahkingori@yahoo.com
}

\begin{abstract}
Purpose: This paper aims at identifying how the Medieval Christian history provides insights, and suggests solutions in regard to present corruption-related social problems in in the modern world. The study is expected to show that the Church is a human organization that is dynamic rather than static, a community that does not have immunity over other forces operating on earth such as corruption.

Methodology: Key data was acquired from literature materials dealing with the history of Christianity during the Middle Ages or medieval period. The second group of literature materials provided information that has to do with the current social moral issues, with special focus on corruption. The study applies narrative method of literature review to fill the gaps on what corruption entails. Both qualitative and quantitative study designs were engaged.

Findings: The desire for power and prestige, simony and investiture, feudalism, sale of indulgences, and nepotism are all identified with the medieval period church history. The Church must be given credit for the effort it put in eradicating those evils, and the modern Church's challenge is to continue fighting for the same. The modern Church has been challenged to learn from the mistakes of the medieval Church and make sure that they are not repeated. Moral depravity, lack of proper education, poverty, land issues, and love of money have been highlighted as the key factors that contribute to the increase of corruption in Kenya and many other countries in Africa. Change of values, instilling of accountability systems, playing a mediating role, and establishing anti-corruption education are stated as the key methods that Christians should incorporate in their fight against corruption.

Unique Contribution to theory, practice and policy: The Church of the medieval period portrayed a clear picture that the whole human society was subject to the will of God. In spite of the many pitfalls that accompanied Christianity, there still remained many faithful people who were true ambassadors of Christ. It must also be known that Christianity deserves unreserved credit for her forefront participation in the development of the modern societies. The church is recommended to take a forefront position in the fight against corruption.
\end{abstract}

Key Terms: Church, Corruption, Education, History, Medieval Period 


\section{INTRODUCTION}

A call for the modern Christian to learn from the history of Christianity during the medieval period in order to be an efficient participant in the fight against corruption is timely. History, which is the study of the past, enables the modern society to solve today's problems (McKay, 1992, p.x). McKay argues that history must be understood well in order to know the factors that shape today's society, $(1992, \mathrm{p} .2)$ with a goal to fight the vice of corruption. The medieval period Church is said to have spread by addition of masses of men, rather than by individuals' conversion as it advanced in its attempt to penetrate the social relations of the day Powicke, p.6). The medieval period, also referred to as the Middle Ages period is the time between A.D.590 to A.D.1517. During that period, there was a rapid numerical church growth largely attributed to the imperial favor experienced by the church during the period preceding it.

Corruption covers a wide sphere of life. The working definition of corruption in this article covers such terms as unfair deals, bribery, tribalism and nepotism, use of power to get rich, mismanagement of funds, denial of one's rights, injustice, dishonesty, discrimination, and oppression. Graft is a slang that is equivalent to corruption and King defines it as acquisition of money or position through dishonest or questionable means (1949, p. I). Corruption is an " $\ldots$ act of bribery ....covering misuse of authority as a result of considerations of personal gain, which need not be monetary." (Bayley, 1966, p.719733). It is also defined as "lack of financial, moral, and intellectual integrity in business transactions." (Anassi, 2004, p.17) Any form of abuse of power entrusted to someone for private or personal gain is corruption. Syed Hussein Alatas, looks at corruption from a wider perspective and defines it as "a betrayal of trust...deception of public body, private institution or society at large." (1990, 1-2).

From a Christian religious perspective, corruption is sin of the "lowest depth of moral deterioration and decay" (Hastings, p.500). Corruption is a major social evil in Africa, and the world as a whole, and has retarded development of many nations. (Anassi, p.9) The "pattern of corruption can be said to exist, whenever a power-holder who is charged with doing certain things, ....is by monetary or other rewards not legally provided for, induced to take actions which favor whoever provides the rewards." (Kibwana, 1996, p.28). Some phrases also illustrate the kind of bitterness that is within the majority of the common people due to the injustices they go through. Corruption, as the word implies is, "the rottenness and stinking of a society polluted by evil." (Mwiti, 2003, p.21)

The political, economic and even the religious institutions must be commended for whatever they have done in their effort to shape the moral values in the society, no matter how small the contribution might be. Lack of a comprehensive document that addresses the problem is not a proof that nothing has been done. The argument at hand is that a time has come when our present social problems should be addressed from a Christian 
historical perspective. A positive critical review of the history of Christianity during the medieval period is a necessity in order to identify how the past can help us to solve the modern escalating problem of corruption in many world countries. The Underground Church affirms that "The visible Church is generally concerned with history through a rearview mirror. It finds justification and reinforcement in tradition. It is an institution with dignity and integrity that is based in history. It often looks to the past for answers to the present and the future" (Boyd, 1968, p.216-217). We would rather do something when it is late, than fail to do anything forever. And if "history is the story of men's efforts to get along with one another" (Reither, 1942, p.v), then this discussion is timely. The purpose of this study is to challenge the contemporary Christian to engage in the fight against corruption using medieval period church history lessons.

\section{LITERATURE REVIEW}

Authors of the history of Christianity during the medieval period have highlighted the role played by the Church on matters of social moral issues such as corruption. According to Cantor, what is happening today in the Church "represents a struggle between its surviving medievalism and attempt to go beyond medievalism (Cantor, 1973, p.3)." It is clear that a study of the Christian medieval period is essential in solving problems associated with corruption, which gives the book a priority in this project. Cantor points out that history will not solve all our social problems but will provide an alternative social model that will provide guidance. According to Powckie, when the medieval church spread by addition of masses of men, rather than by conversion as it advanced in its attempt to penetrate social relations of the day, it was a sign of its fall into corruption (Powckie, 1935, p.6). He sees the history of the church as the record of the gradual and mutual adaptation of Christianity and paganism to each other, the end result being corruption.

In his book, Christianity Through the Centuries: A History of the Christian Church, Cairns (1981, p.13) supports the argument raised by Cantor by taking a pessimisticoptimistic approach towards history. Cairns explains that, the social problems affecting the people of the areas where the church has been active, can be understood and solved in the light of historical developments. The role of Church history in the life of a believer, as an instrument of eradicating social evils is well stated. The argument raised by both Cantor and Cairns is that every Christian who desires to emulate the good examples of the past and avoid the mistakes made, can benefit from a study of Church history.

Margaret Hastings' approach to medieval civilization brings into light the bond of contemporary community with the people of the middle ages, and so enriching a better understanding of the relationship between the two. In her book, Hastings discusses in depth the issues of simony and lay investiture, defining simony as "buying and selling of church offices, an evil likely to crop up in any large - scale bureaucracy in which offices 
provide valuable income and power" (1971, p.121). Contributing on the same subject, Southern explains how simony, nepotism and land issues polluted the purposed mission of the church and affirms the "church was in danger of being swallowed by the world" (1978, p.130). In that period, it was difficult to keep the matter of appointments free from family and monetary considerations. Bolton (1983, p.18) has affirmed that simony was very common during the medieval period and so supports the argument that has of both Hastings and Southern. It is clear that the laymen exerted a disproportionate influence over the Church appointments, a move that can be attributed to the rise of corruption.

In his The Medieval Church: Success or Failure?, Bachrach highlights, monastic life and Crusades as Medieval social issues that illustrate how the Church got involved into corrupt businesses. Bachrach states that, the Cisterncians monks "used their privilege of exemption from paying custom duties and tolls to transport the goods of other merchants" (1972, p.83). On the same discussion, Southern gives a picture on how ecclesiastical office intermingled with the secular life and what came out of that. Some bishops and rulers had a tendency of treating the church as a branch of secular life.

Medieval civilization, as Cantor (p.505) puts it, was somehow in danger due to violence extremism and suicidal destruction of its fundamental values. Pope Urban II told the crusaders to expect to acquire new wealth and power, encouraging them by stating that they were heading to a land that "flowed with milk and honey and the delights of heaven" (Combee, p.227). A key reason behind the commissioning of the crusades was because Popes aimed at increasing their power and prestige. And as the saying goes, power corrupts. Most church leaders of the day "turned spiritual benefits into a money-making advantage" (Shelly, p.189). The crusades, whose initial aim was to fulfill a spiritual need, were discovered to be effective programs of raising money. It will also be of great importance to discover whether there are certain spiritual benefits that the church in Africa is taking advantage of, by being used as a means of making money. Christians are expected to portray "a type of conduct above that of ordinary men..." (Bevan, 1932, p.23) when it comes to moral issues.

According to Mugambi, "Scriptures rather than social institutions should provide a standard against which piety of individuals and organizations can be tested and challenged" (1989, p.14). Mugambi is concerned that the church leaders have to a certain extent failed to openly condemn and combat evils in the community. It is a shame to see many professing Christians who are daily arraigned in court because of corrupt practices. One of the challenges brought forward is that each individual has a role to play in the process of eradicating corruption. Authors seem to agree that values and attitudes of citizens towards corruption need to be transformed, in order to acquire good results. From a Christian-historical perspective, it is the reformed individuals that would normally initiate reforms. Establishment of institutions alone is not enough. According to Rasheed, author of Ethics and Accountability in African Public Services "virtually every country 
has established a number of institutions to promote ethics and accountability" (Rasheed, 1993, p.5). This plays an important role in showing what has already been done in relation to corruption. In his Spiritual Leadership: Moving People on to God's Agenda, Blackaby attributes the use of secular approaches by Christian leaders as one issue that has contributed to the rise of corruption (2001, p.9). He argues that the world needs religious leaders who are on God's agenda and not on their own. According to Blackaby, there are many leaders who are discovering that the most important leadership aspirations should not be wealth or money (2001, p.264). Temptations that have to do with material wealth as Blackaby puts it, can easily lead astray Christian leaders even for those that work with the Church (p.271).

Mark Shaw looks at the Church as an institution with a purpose "of fighting structures of poverty and justice" (1996, p.20). Since corruption is a form of social injustice, Shaw's contribution is essential. Just as Shaw says, the Christian witness is very important in that, "it points to the redemptive heart of the rule of God in a way that is not true of other emphasis..." (p.297). The purpose of genuine Christians is to show others the path that leads to justice and righteousness that is free from corruption. As Kivutha Kibwana states, "people at all levels of society often lack vital information about things that concern them" (1997, p.3). When people lack vital information, they lack the capacity to be effective as they should be. On the same argument, Mute (2002, p.99) says that education has the purpose of encouraging and empowering the civil society and individuals to play an active watchdog role to safeguard public resources in various parts of the country. The trend will enable the communities to get into action-oriented initiatives in search for justice (Blackaby, p.4).

\section{MATERIALS AND METHODS}

Both qualitative and quantitative study designs were employed in this study. Although a lot of information was drawn from available literature materials, data from people working with organizations that are directly involved in the fight against corruption were given priority as they were the primary source. Through interviews and email correspondences, information was received from National Council of Churches of Kenya (NCCK) and Ethics and Anti-Corruption Commission (EACC), formerly Kenya AntiCorruption Commission (KACC). Other organizations included the Kenya Human Rights Commission (KHRC) and Transparency International - Kenya chapter. 
The various views from different sources have been evaluated positively, and from a Christian perspective. Literature materials included textbooks, journals, magazines and newspapers. First, the books and other literature materials targeted will be those dealing with the history of Christianity during the Middle Ages or medieval period. The second group of literature materials provided information that has to do with the current social moral issues.

The authenticity of every information was evaluated before being accepted as appropriate resource for this study. The information was then classified according to their content. The primary resources were compared with the data collected from secondary resources before they were accepted as part of the study. They were recorded in a narrative format and considered in the findings section of the study.

\section{CORRUPTION IN THE CHRISTIAN MEDIEVAL PERIOD}

What is happening today in the Church "represents a struggle between its surviving medievalism and attempt to go beyond medievalism." (Cantor, 1973, p.3) In his book, Christianity Through the Centuries: A History of the Christian Church, Cairns (1981, p.13) explains that, the social problems affecting the people of the areas where the church has been active, can be understood and solved in the light of historical developments. Margaret Hastings' approach to medieval civilization brings into light the bond of contemporary community with the people of the middle ages, and so enriching a better understanding of the relationship between the two. In her book, Hastings discusses in depth the issues of simony and lay investiture, defining simony as "buying and selling of church offices, an evil likely to crop up in any large - scale bureaucracy in which offices provide valuable income and power" (1971, p.121). In that period, it was difficult to keep the matter of appointments free from family and monetary considerations. Bolton (1983, p.18) has affirmed that simony was very common during the medieval. It is clear that the laymen exerted a disproportionate influence over the Church appointments, a move that can be attributed to the rise of corruption.

Authors of the medieval history have also proved that there were men of the church who used power to put some limits on corruption especially the terrible violence of feudal times. The cry for change by reformers during the Middle Ages came because of the corruption of the Popes who had become world rulers and had a lot of power. An exceptionable case would be Pope Gregory I, also referred to as Gregory the Great, who was never comfortable with worldly powers. To him, "pride was a vicious hound that dogged him relentlessly." (Shelly, p. 168) The monastic movement also made important contribution to the reforms whose purpose was to bring the straying Church back to the track. This is especially seen in the provision of biblical texts in Latin, Greek and Hebrew whose purpose was to help people understand the content of Christianity (Price, 1992). 
In his The Medieval Church: Success or Failure?, Bachrach highlights, monastic life and Crusades as Medieval social issues that illustrate how the Church got involved into corrupt businesses. Bachrach states that, the Cistercians monks "used their privilege of exemption from paying custom duties and tolls to transport the goods of other merchants." (1978, p.83). On the same discussion, Southern gives a picture on how ecclesiastical office intermingled with the secular life and what came out of that. Some bishops and rulers had a tendency of treating the church as a branch of secular life. Mckay has pointed out that, "by the eleventh century, wealth and lay interference caused corruption" (p.218). During that period, research shows that the office of Pope was frequently bought and sold, as the papacy was corrupt and materialistic.

Little doubt is left to indicate that the crusades of the medieval age period made the problem of corruption to escalate. The review carried out shows that what the church leaders referred to as holy wars contradicted Jesus message that his kingdom cannot be gained through the sword. Pope Urban II told the crusaders to expect to acquire new wealth and power, encouraging them by stating that they were heading to a land that "flowed with milk and honey and the delights of heaven" (Combee, 1994, p.227). A key reason behind the commissioning of the crusades was because Popes aimed at increasing their power and prestige. And as the saying goes, power corrupts. Most church leaders of the day "turned spiritual benefits into a money-making advantage."(Shelly, p.189). The crusades, whose initial aim was to fulfill a spiritual need, were discovered to be effective programs of raising money. It will also be of great importance to discover whether there are certain spiritual benefits that the church in Africa is taking advantage of, by being used as a means of making money. Christians are expected to portray "a type of conduct above that of ordinary men..." (Bevan, 1932, p.23) when it comes to moral issues.

Historical records show that, "clerical immorality reached the lowest depth in the tenth and eleventh centuries, when Rome was a sink of iniquity, and the popes themselves set the worst example." (Schaff, 1992, p.331). The Christian medieval period is a historical period when values upheld by the Church were about to be swallowed up by the world. The major forms of corruption have been identified and are the subject of discussion in this section. They have to do with the desire for power and prestige, simony and investiture, feudalism and land issues, sale of indulgences, and nepotism and cronyism.

Desire for Power and Prestige: During the Medieval period, a major contributory to the evil of corruption within the Church was the leaders" hunger for "power as they saw themselves as world rulers." (Shelly, 1982, p.160). It is a pity that even the landmark of the Gothic cathedrals that were built high and higher than other buildings, did not just represent spiritual testimony but they also represented the position held by the Church and its leaders. According to Mckay, these cathedrals also reflected power and prestige to both the church and the community. (1992, p.252). The medieval period also reflected a time of economic power and civic pride of the great cities, something that had a great 
influence on the Christianity of the day. Mackay refers to this development as "religious heresy", that rose when the existing Christian religion was unable to meet the needs of the members of the community whose problems needed humble leaders. A true religion was expected to be compassionate, focusing on the needs of every member of the community. An exceptional leader of the time was Gregory the Great, a pope who referred to himself as "the servant of the servants of God," (Shelly, 167) a move that was contrary to the escalating desire for prestige and power of the Church leaders of the day. Gregory indicated that each person is of value before the eyes of God. It was a time when a large number of people relied on the Church for spiritual guidance.

Innocent III believed that he was the "Vicar of Christ," and believed that he held supreme power both spiritual and secular leaders were all under his authority. He made use of the Roman law that allowed for a centralized system of authority.

Simony and Investiture: Simony has been defined as "the buying and selling of church offices." (Hastings, p.121). The concept has its origin in the story of Simon Magus who was trying to buy the gift of the Holy Spirit (Acts 8:18-20) from the Apostles. The old heresy was now extended to the appointment of clergy to Church offices. It went to the extreme dimension where the laity were also involved. Lay investiture, a situation where bishops and key Church leaders were chosen by secular leaders, was related to simony, and the reformers saw it as "the fundamental evil of the sinful perversion of God's order." (Frank, 1995, p.58). Just as the definitions indicate, simony was different from lay investiture. But they both were corrupt acts soiled the holy institution. It was very common for lay lords to sell important ecclesiastical offices to unworthy self-seekers. (Hollister, 1975, p.216). Simony seemed similar to lay investiture in a situation where simony involved lay individuals. The act made matters worse by making the contagious sin affect almost everyone negatively. The buyers of the offices would in turn exploit their tenants and other subordinates in an effort to recover their expenses. It was a type of an ecclesiastical corruption that was more evident in Rome than anywhere else.

Leeming also sees, "simony as one of the main abuses found in the middle age church." (1980, p.124). There is clear evidence that Bishops and other Church leaders were very much accustomed to selling holy things during the medieval period. Some of the posts in the Church made men very wealthy, and to make the matter worse many of these posts were sold to people that had never trained as priests.

The problem of investiture arose in the context of the feudal system, a concept that will be looked in depth in the next section. The archbishops, bishops and other clerics ended up becoming the vassals of kings and other lay lords. It was possible for the kings and other lay lords to interfere with election of church leaders. Again, the upper clergy were for the most part from lay nobility (Hastings, p.121). This unorthodox way of doing things caused a very serious controversy, as it did not match with the mission of the 
Church. There arose a "dispute as to whether the feudal lord or the pope should grant an ecclesiastical feudal vassal" (Cairns, 1981, p.194). It was a question on who was incharge of secular matters or ecclesiastical matters. Again, it was a question as to how much the Church should be involved in issues that are non-spiritual and also how much the secular leaders should be involved in spiritual issues.

It has been argued that simony is an evil likely to crop up in any large-scale bureaucracy, of which offices provide valuable income and power (Hastings, 121). For that reason, it was difficult to keep the matter of appointments and election free from family and monetary consideration when "the filling of ecclesiastical offices was the responsibility of the secular rulers" (Southern, 1978, p.124). Because of this, a reform that would bring a change was urgently needed. There was a great need to do away with the trend that was contradicting the mission of universal Christianity.

Feudalism and Land Issues: Feudalism can be described as a system of political organization of the medieval period that was based on possession of land where the local lord provided government in the immediate area where he owned the land. Feudalism of the church land tended to secularize the Church and so distracting her attention from spiritual things to mundane interests. The gifts of land by pious or repentant men, seeking to atone for a life of sin, remained in the hands of the Church and this made the church to be influenced by the feudal system (Cairns, 1981, p.193). Many innocent people willed their property to the Church in a last effort to secure salvation. It was a time when the influence of the Church penetrated almost all social relations through and through (Powicke, 1935, p.6). In the process, the Church is said to have fallen right into step with feudalism, as it became one of the greatest landowners of the time. Feudalism within the Roman Church in turn led to a decline in clerical morals. This is because the dual allegiance to the pope and the feudal lord created a division of interests (Cairns, p.193). Many leaders in the Church fell into material temptations and so destroying the good name of the Christ's Church. The Church was so much a part of medieval life and there was no way it could escape its inclusion in the feudal system. Both bishops and abbots were becoming vassals and so pledging loyalty to higher lords. Christians, whose teaching states that all people are equal, failed to put that into practice in their dealing with the feudal system. Feudalism was a kind of comprehensive social and economic order that ruled every sphere of life and it is clearly noted that even the Church was not able to escape that evil system. The Church seemed to care less for the many people who suffered under the feudal system. Feudalism is a system that corrupted both the secular and religious institutions of the day, as it never abided with the principle of respecting human rights. In many places, the church was the largest landowner and it collected taxes, mastered forces, and carried many other functions usually associated with secular government. While commissioning the crusaders, Pope Urban II had urged the Christians to take up the cross and strive for a cause that would lead to not merely spiritual rewards, but also material gain as well. The major problem in this development rose when 
"genuine faith was often combined with personal greed." The desire for wealth especially the land and money for building cathedrals and churches lead the churchmen to forget their priority task. It has been discovered that corrupt Church officers were to be found throughout the era of medieval period (Hollister, p.199).

Disputes over land and privileges had become regular issues to an extent that the pastoral office was normally preoccupied in dealing with such disputes rather than more concrete spiritual matters. The history of the medieval period reveals many instances when the work of God was combined or compromised with the acquisition of material advantage especially land, as was evidenced by the crusades. The dream of liberating Jerusalem and the Holy Land from the infidel and reopening them to Christian pilgrims was reinforced greatly by the lure of new lands and vast wealth. The first crusade succeeded in acquiring a long strip of territory along the eastern coast of the Mediterranean where it created the feudal Latin Kingdom of Jerusalem that survived until 1291 (Shelly, 189). Crusades, according to Hollister (p.185), represented a fusion of three characteristic medieval impulses of piety, pugnacity, and greed. An example of this greed would be the Children Crusade of 1212 that has been termed as the saddest incident in the history of crusades. Many of the children perished and the rest were sold into slavery in Egypt. Greed is a vice that is hard to separate from corruption.

The discussion at hand can be of much benefit if the concept of Christendom, that has to do with the marriage between the Church and state, can be well understood. It was a development that led to the deterioration of the Church of the medieval period (Wamue, 2003, p.130). In the medieval period, there were times when some Church leaders also served as noblemen carrying the responsibility of supporting the political government. At such times these Church leaders would have limited time to invest into their spiritual responsibilities as most of their time was consumed by secular engagements. It was an open practice of corruption practiced by those that were expected to condemn it. According to Muller (1952, p.259), the desire to make a fortune in the Middle Ages, corrupted the clergy and the nobility class far more than the ordinary people who did not profess high unworldly ideals.

Sale of Indulgences: The false doctrine that one can be free from the temporal penalty of sin by paying some money also contributed to the corruption of the medieval church. The signs of corruption of the holy cause were apparent in what came to be referred to as the sale of indulgences. An indulgence was the document that was bought to free one from sin and it was associated with the sacrament of penance (Cairns, p.282). Penance which has to do with atoning for the sinful deeds involved some sort of payment with a purpose of restoring justice and peace (Frank, p.17). The sinner's wealth and social position determined the amount he or she would be charged for the sale of indulgences, a trend that gave rise to corruption. After the first crusade, which has been considered to be the most successful of all, the original frenzy cooled and what followed was desire for money 
to meet the many needs associated with the new Christian lands in the East. In order to solve this urgent need, the Medieval Church leaders used the sale of indulgences as the key method of raising the needed finances.

According to Christian medieval history, the irrepressible demand for indulgences and also the questionable activities of those who became the pardoners was a constant worry to the Church (Swanson, 1996, p.219). It was a clear business of buying and selling. And it has been confirmed that, as the sellers marketed their commodity of indulgences, they sometimes oversold their goods. For many people, selfishness and concerns for the worldly things slowly replaced devotion to God. One of the key instances when the sale of indulgences gained strong roots was during the crusades, famously referred to as the holy wars. The purpose of the crusades was supposed to clean the Holy Land by getting rid of the unbelievers. But some Church leaders of the day turned whatever was initially spiritual benefits into a money-making adventure.

Nepotism and Cronyism: During the medieval period, nepotism or the promotion of one's relative was commonly prevalent. Nepotism is closely related to tribalism, a dangerous form of corruption that the Church of the medieval period did not escape. Many Church leaders, even some popes were notorious of nepotism in their appointments, according to Latourette (p.151). Church affairs were conducted as family businesses, a trend that demoralized the divine institution. In some instances, the custodians of the cathedral "derived their shares by inheritance from their great grandfather, a priest of the church." (Southern, 1978, p.129). Southern argues that, they kept their agents always in the church to look after their interests, not God's interests. Although it is generally believed that it is those with a call from God that would be found serving in the Church, a different trend had risen up that encouraged nepotism, an evil that should be discouraged even in the secular society.

According to the study carried out, it has been discovered that many monasteries of the medieval period were also closely connected to tribal society, another development that contradicted the vision and mission of Christian Church. There were cases where an abbot would be chosen from the clan to which the founder belonged, as was the case with the early abbots of Iona who belonged to the family of St. Columbia, the royal race (Bachrach, p.12). It is a practice that made the Church unqualified to point out the social evils within the community of which it is a part of, due to her questionable character.

The Cistercian order did not suffer from anything more than from corruption. The Cistercian monks are said to have "taken the lead in the monastic withdrawal from the world, but the world followed them and they were unable to resist its temptations" (Cantor, 1969, p.407). Decay of the Cistercian order had its roots in the inner causes. The riches the order accumulated as a result of industry exercised a detrimental influence on the life of the brothers (Jackson, 1909, p.121). They started leading a lax life, which 
resulted to corrupt dealings. Research also shows that the rapid growth of the Dominican order was not just due to its qualities, but also due to protection from powerful friends among the kings, nobles and even popes (Jackson, p.481). In 1239, when the secular arm was placed at the disposition of the Church, Fredrick II is said to have offered his protection to the Dominicans as inquisitors. The Dominicans also enjoyed lavish privileges from the popes. In 1255, Alexander IV appointed the Dominicans the provincial inquisitors for France. Corruption had spread throughout the hierarchy of the Church starting from the top to the bottom. It had penetrated almost every office and ministry of the Church of medieval time. In order to eradicate the problem, an overhaul of the whole system was a necessity. However, and in spite of the deformed picture of the medieval Church, there was still hope. The Church was not dead, it was only sick. In its sickness the Church was still the conscience of the society as it is proved in the next section.

\section{CONCLUSION}

It is clear that the medieval period church did not provide a pure apostolic Christianity, which was the main need of the society it served. In many instances, the church accommodated itself to existing circumstances that were part of the institutions of the empire (Cantor, p.77). The product was Christendom, a development that was accompanied by both benefits and liabilities that have continued within Christianity up to the present generation. One reason behind this development was because Church membership increased mainly as a result of state affairs, where people joined the church in masses with the absence of true conversions. Christian leaders of the medieval period carried the heavy blame in relation to the rise of social evils of the time. The leaders of the Church made the "mistake of urging believers to have a fuller appreciation of the value of the things of this world without balancing with the spiritual things (Charles, 1973, p.9). It is true that as an integral part of the medieval life, the Church could not escape its involvement in such products of the time as the feudal system, but it will be hard for that to be accepted as a license for the many social evils that took place. The Church failed to decide conclusively as to what extent it should be involved in secular matters. Medieval records show that even the papal office fell into decay after becoming a prize that was sought by even the local Roman nobles.

On the other hand, there were also several positive things that are attributed to the medieval Church members. No matter how many Christians strayed away from the faith, there was still a remnant that stood to defend the truth. Many monastic groups and synods stood up firmly in the name of the Church and demanded reforms. Appreciation should be given to both the individuals and groups that were the lights in the middle of darkness by attempting to make positive moral influence to those that were straying away from the truth. In general, and from a wide perspective it can concluded that the medieval Church gave a clear picture that every human society is subject to the will of God. As a social 
institution, the Church of the middle ages proved that it was not just a divine body but it was also fully human.

The present-day society is still being haunted by the medieval social environment. But the Church is a key institution that has a role of increasing awareness to the public in order to change attitudes and beliefs that breed corruption. The witness of the Church is essential in the fight against corruption as its focus is on the redemptive heart of the rule of God, something that is lacking in other emphases. (Shaw, 297) In comparison with other social institutions such as the government, the Church has a forefront responsibility in the work of combating corruption. In supporting this view, Mugambi argues that the Church has the authority from above for condemning such social evils as corruption (1989, p.14). Religion rather than secular institutions should provide the standard against which individuals and organizations can be tested and challenged on matters of corruption.

The medieval Christian history provides insights, and suggests solutions in regard to present corruption-related social challenges especially in continent of Africa as a whole. The study on the history of Christian medieval period is also intended to prove that the contemporary Church has two faces: divine and human. Being a divine institution, it represents Christ on earth as a community to be emulated on matters of righteousness and social justice. At the same time history show that the Church is a human organization that is dynamic rather than static, a community that does not have immunity over other forces operating on earth such as corruption. Eradication of corruption can be furthered by applying lessons learnt from the history of the Christian medieval period. The church pulpits, Christian seminars and Sunday school classes should be used more than ever, to address the problem with a lot of seriousness. Although many Christians are in a dilemma, confused and unsure of what to do when faced with a case where the situation demands them to bribe, which is a form of corruption. Christians worldwide should seek to have a personal experience with Jesus and be eager to present Gospel message, untainted by corruption.

\section{RECOMMENDATIONS}

This paper asserts that the Church in Kenya "has a divine duty to liberate humanity from all forms of oppression" (Wamue, p.137) especially those that relate to issues of corruption. If contemporary Christians will adhere to the fundamental orthodox Christian teachings, a reformed community that is free from corruption will be realized in the world. According to Blackaby, "as secular writers are embracing Christian teachings with the fervency of first-century Christians, Christian leaders are inadvertently jettisoning many of those same truths in an effort to become more contemporary" (Blackaby, p.11). Below are some of the key recommendations: 
Change of Values: Time has come when the Christian community should change its values for the betterment of the world as a whole. This is a necessity in the fight against corruption. The past must be analyzed and interrogated in order to get down to building a new order where justice is practiced (Mute, p.331). Just like any other fight against a social ill, the fight against corruption must be owned by the very people who have been negatively affected by the vice. The state or the government expects the Church to be an institution where integrity is priority. The researcher agrees with Mwiti's statement that, "the better alternative to corruption is integrity" (p.164). The presence of corrupt practices within the Church organizations becomes a betrayal of the trust, however minor these practices may be. It is recommended that all members of the clergy and other leaders of the Church of Jesus Christ should by all means avoid tarnishing the good name of the Church by misusing the offices given to them by all means.

Instilling Accountability Systems: The Church should be on the forefront in instilling accountability systems in her various organizations. The absence of such services as auditing of financial books in many organizations has to a certain extent encouraged corruption. Church leaders should know that preparing good financial records is essential. Failure or success in doing that will reflect either a good or a bad stewardship, and this will have a strong bearing on the future of the Church. The modern Church has an advantage in doing a better job than the medieval Church due to the availability of efficient tools such as computers and trained personnel that would contribute a great deal in implementing accountability.

Again, it is hereby recommended that the contemporary Christians should be careful on how they view material things as they either promote or demoralize their position in the society. During the medieval period it was more of the latter than the former that took place. Many are the instances when the desire for material things did not go well with God's plan for His people. The things acquired in this world should not be seen as an end but as a means to the end, in which case, the end will be to do the will of God, no matter in which circumstances one is.

Playing a Mediating Role: The Church should also take a mediating role in situations where forgiveness and reconciliation is required due to corrupt social evils committed in the past. The Church is better placed than any other institution because it has an access to its members who are drawn from diverse ethnic backgrounds. The reconciliation and forgiveness processes will not only require people to acknowledge that they can change, but will also free people by giving them hope, a development that can bring positive change to the wider Kenyan community.

Church leaders are challenged to learn from the medieval period where the bishops concentrated a lot on the social, political, and economic activities and so neglecting their major calling which was spiritual, as it is evidenced in chapter four of this research work. 
If Christians would avoid mingling sacred with secular things as it happened during the Middle Ages, they will earn the credibility of serving as mediators.

The Church should carry out her responsibility by participating fully in making the world a better place than it is now. Christians should realize that, "The Church has the task of summoning the whole world to submit to the dominion of Jesus Christ" (Bonhoeffer, p.347). Bonhoeffer, a Christian ethicist, states that it is the duty of the Church to help the government to come to an understanding of itself. In other words, the true guidelines to leadership must originate from God himself since He is the author of life.

Establishing Anti-Corruption Education: It is recommended in this research work that, an anti-corruption education program be initiated that will cater for all citizens. All categories of citizens in a society need this type of education. Unlike in the medieval period where the majority had no access to education, in the contemporary society, almost every citizen can be reached with information on corruption through the media and other institutions that deal with educating the society. Education on corruption will empower the oppressed masses to rise up and participate in addressing and arresting the problem. A formal education curriculum for nursery, primary, secondary, colleges and even universities should be designed. Determination of what would constitute the anticorruption education values rather than partisan propaganda should be guided by the minimum standards set out in that specific curriculum (Mute, p.156).

The Christian anti-corruption education providers must be able to acknowledge that their duty involves a broad social transformation responsibility of all citizens, and not just targeting a few individuals. Those to benefit from the education should be sought as much in the rural areas as in the urban centers. The education should also focus on both the educated elite as much as the non-literate population. The education proposed should challenge members of the community never to compromise whenever and wherever they are faced with corrupt dealings. Education is expected to remove the citizens from the life with the mentality of selfishness into a civilized form of life where persons will hesitate to do wrong, since their conscience has been fortified.

Being Examples: During the medieval period there arose several reforming groups such as Cluny, Franciscans, and Cistercian order that took an active role in the fight against corruption of the time. There were also individuals such as Gregory VII and Francis whose practical lives can be pointed as role models. The modern Christians should borrow a leaf from that. "History is replete with examples of Christian men and women exerting spiritual leadership upon secular society” (Blackaby, p.22).

Individual Christians, families, and groups should be examples to be followed by other members of community due to their moral uprightness. Christians should know that although they live in the world, they do not belong to the world. This lesson is well stated 
in their Master's prayer found in the Gospel of John chapter seventeen, verses fifteen and sixteen which says, "My prayer is not that you take them out of the world but that you protect them from the evil one. They are not of the world, even as I am not of it. Sanctify them by the truth; your word is truth" John 17:15-17). Jesus Christ on whose foundation the Church lies teaches that it is possible to live in a corrupt world and not get corrupt.

Positive Attitude Toward Other Institutions: The Church should be on the forefront in supporting other institutions that are actively involved in curbing corruption. A good example is the government itself, which is can play the role of sensitizing the public on the dangers of corruption. Christians that are working in the public sectors as well as in the private should be challenged to take a leading role in the fight against corruption in their respective areas of service. The Christian life should be a power in all levels of communities that has both sweetening and purifying responsibilities (PACLA, p.349). It depends on Christ's strength and for Christ's sake in making positive influence to the people.

Restitution: Those who acquired public or personal properties through corrupt means should be encouraged to return what they stole. No cases of restitution of the medieval period have been recorded in the research work carried out, an evidence that questions the credibility of the Christianity of the time. Contemporary Christians should avoid that mistake, as repentance should go hand in hand with restitution. There are many Kenyans who are patiently waiting to know the situation of their lands and other properties that for one reason or another were dispossessed. The situation is even worse when the culprits are those also claim to be Christians and are holding positions of leadership. Samuel, the aged prophet and priest of the Old Testament section of the Christian sacred writings is a man that every Christian should emulate. With a lot of confidence Samuel (I Samuel $12:: 3)$ stood before the Israelites and raised his case without fear:

Here I stand. Testify against me in the presence of the Lord and

his anointed. Whose ox have I taken? Whom have I cheated?

Whom have I oppressed? From whose hand have I accepted a

bribe to make me shut my eyes?

Churches and individual Christians that have taken wrongfully the property of others are recommended to return and ask for forgiveness where opportunity is provided for such actions. As it has been noted above, Christians should be good examples on issues of integrity and transparency, and should know that they are not just accountable to man but also to God the creator of heavens and earth. 
European Journal of Philosophy, Culture and Religious Studies

ISSN 2520-0445 (Online)

Vol.5, Issue 1, pp $38-57,2021$

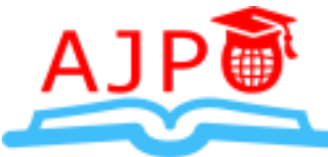

www.ajpojournals.org

\section{REFERENCES}

Alatas, Syed Hussein. (1990). Corruption: Its Natures, Causes and Functions. Aldershot, Alfred A. Knopf.

Anassi, Peter N. (2004). Corruption in Africa: The Kenyan Experience. Victoria, BC:

Bachrach, Bernard S. (ed.). (1972). The Medieval Church: Success or Failure?. New

Bayley, D. H. (1966). 'The Effects of Corruption in Developing Nations,' Western

Bevan, Edwyn. (1932). Christianity. London: Oxford Press.

Blackaby,Henry T. and Richard Blackaby. (2001). Spiritual Leadership: Moving People

Bolton, Brenda. (1983). The Medieval Reformation: Foundations of Medieval History.

Bonhoeffer, Dietrich. (1970). Ethics. New York: The Macmillan Company. Books.

Boston, MA: Houghton Mifflin Company.

Boyd, Malcolm (ed). (1968). The Underground Church. New York: Sheed and War

Cairns, Earle. (1981). Christianity Through the Centuries: A History of the Christian Cambridge University Press.

Cantor, Norman F. (1973). The Meaning of the Middle Ages: A Sociological and Cultural Catholic World News Reporter. "Kenya Church Leaders Demand End to Government Charles, Rodger. (1973). The Church and the World. Dublin, Indiana: The Mercier Press. Christianity. Grand Rapids: Baker Book House.

Church. Grand Rapids, MI: Zondervan.

Chweya, Ludeki, J. Tuta and Kichamu Akivaga. (2005). Control of Corruption in Kenya: Legal-Political Dimensions 2001-2004. Nairobi: Claripress Limited.

Claripress Limited. 
European Journal of Philosophy, Culture and Religious Studies ISSN 2520-0445 (Online)

Vol.5, Issue 1, pp $38-57,2021$

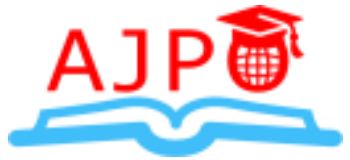

www.ajpojournals.org

Combee, Jerry H. and Kurt A. Grussendorf. (1994). Since the Beginning: History of the Corruption in Kenya: Legal, Political and Socio-Economic Perspectives. Nairobi: Corruption." Catholic World News, Nairobi, (Feb. 07, 2005), 1.

D. C.: The Catholic University of America.

Daily Nation. "How the Government is Winning the War Against Corruption." Daily EndTime Team. "Money for Prayers: The Biblical Truth in Regard to Controversial England: Aveburg.

Frank, Isnard Wilhelm. (1995). A History of the Medieval Church. London: SCM Press. Hastings, Margaret. (1971). Medieval European Society 1000-1450. New York: Rondom History. Boston, MA: Allyn and Bacon, Inc.

Hollister, C. Warren. (1975). Medieval Europe: A Short History, $5^{\text {th }}$ Edition. New York: House.

Jackson, Samuel Macauley (ed.). (1909). The New Schaff-Herzog Encyclopedia of Kibwana, Kivutha, Smokin Wanjala, and Okech-Owiti. (1996). The Anatomy of King, Hans. (1961). The Council, Reform, and Reunion. New York: Sheed and Ward. King, William Joseph. (1949). Moral Aspects of Dishonesty in Public Office. Washington Latourette, Kenneth Scott. (1965). Christianity Through the Ages. New York: Harper \& Leeming, Donald. (1980). World History Book I. Nairobi: Longman Kenya. London: Edward Arnold (Publishers) Ltd. Longman Kenya. Massachusetts:Blackwell Publishers. McKay, John, Bennet D. Hill, and John Buckler (1992). A History of World Societies. Mugambi, J.N.K. (1989). African Heritage and Contemporary Christianity. Nairobi: 
European Journal of Philosophy, Culture and Religious Studies ISSN 2520-0445 (Online)

Vol.5, Issue 1, pp $38-57,2021$

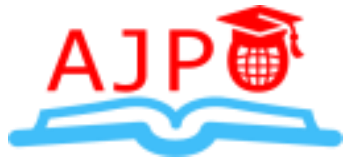

www.ajpojournals.org

Muller, Herbert J. (1952). The Uses of the Past: Profiles of Former Societies, New York:

Mute, Lawrence, Wanza Kioko and K. Akivaga (eds). (2002). Building an Open Society:

Mwiti, Gershon. (2003). When the Best is Corrupt. Nairobi: Oasis Africa.

Nairobi: Acton Publishers.

Nation. Nairobi, $13^{\text {th }}$ April, 2005, 13

Nduta's Faith Healing,” End Time Christian News, No.79 (Nairobi: June, 2006),1.

Neill, S. C. (1986). A History of Christian Missions. Harmondsworth, New Tork: Penguin on to God's Agenda. Nashville, TN: Broadman \& Holman Publishers.

Oxford University Press.

Penguin Books.

Political Quarterly, Vol. XIX, No. 4, December 1966, 719-732.

Powicke, F. M. (1935). The Christian Life in the Middle Ages and other Essays. London:

Price, Betsey Barkay. (1992). Medieval Thought: An Introduction. Cambridge,

Publishers.

Rapids, MI: Wm. B. Eerdmans Publishing Company.

Reither, Joseph. (1942). World History at a Glance. New York: The New Home Library. Religious Knowledge. New York: Funk \& Wagnalls Company. Row, Publishers.

Schaff, Philip. (1991). History of the Christian Church: Middle Ages. Vol. IV. Grand Shaw, Mark R. (1996). The Kingdom of God in Africa: A Short History of the African

Shelly, Bruce L. (1982). Church History in Plain Language. Dallas, TX: Word

Southern, R. W. (1970). Western Society and the Church in the Middle Ages. New York: 
European Journal of Philosophy, Culture and Religious Studies

ISSN 2520-0445 (Online)

Vol.5, Issue 1, pp $38-57,2021$

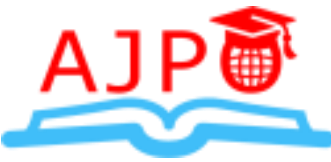

www.ajpojournals.org

Southern, R. W. (1978). The Making of the Middle Ages. London: Yale University Press.

Swanson, R. N. (1996). Religion and Devotion in Europe, c. 1215 - c. 1515. Edinburgh: The Politics of Transition in Kenya. Nairobi: Claripress Limited. Trafford Publishing Limited.

Wamue, Grace and Matthew Theuri (eds.). (2003). Quests for Integrity in Africa. World in the Christian Perspective. Pensacola, Florida: A Beka Book. York: Holt, Rinehart, and Winston, Inc. 